\title{
URGENSI PERAN AKTIF HAKIM PADA PERADILAN TINDAK PIDANA INFORMASI ELEKTRONIK
}

\author{
Anggita Doramia Lumbanraja \\ Fakultas Hukum, Universitas Diponegoro \\ Jl. Prof. Soedarto, SH, Tembalang, Semarang, 50275 \\ anggitalumbanraja@live.undip.ac.id
}

\begin{abstract}
Nowadays, cyber crime have been increasing very sharply since 2018. With the limitations of existing legislation, the judge should take an active role in finding material truth in this criminal cases. This article discusses about the urgency of the active role of judges in cyber crime cases, especially in Electronic Information Crimes. The current Criminal Procedure Code does not adequately accommodate the needs of the legal procedural, especially in the evidentiary provisions. Therefore, the judge actively made a legal breakthrough in presenting electronic evidence as crime evidence, even though the Criminal Procedure Code does not regulate it. However, it is not enough to be there, The Judge should also actively in finding the law.
\end{abstract}

Keywords: Judge; Crime Evidence; Cyber Crimes

\begin{abstract}
Abstrak
Dewasa ini, kasus Tindak Pidana Informasi dan Transaksi Elektronik (ITE) meningkat sangat tajam sejak tahun 2018, beberapa tahun setelah kita memasuki Era Post-Truth. Dengan keterbatasan peraturan perundang-undangan yang ada, hakim harus berperan aktif dalam mencari kebenaran materiil dalam kasus tindak pidana ini. Artikel ini membahas mengenai sejauh mana pentingnya peran aktif hakim dalam proses peradilan Tindak Pidana ITE khususnya pada Tindak Pidana Informasi Elektronik. KUHAP yang berlaku saat ini tidak cukup mengakomodir kebutuhan hukum formil, terutama pada ketentuan pembuktian. Oleh karena itu hakim secara aktif melakukan terobosan hukum yakni menghadirkan bukti elektronik sebagai alat pembuktian meskipun tidak diatur di dalam KUHAP. Hakim harus berperan aktif tidak hanya melakukan penerapan hukum namun harus mampu melakukan penemuan hukum.
\end{abstract}

Kata Kunci: Hakim; Pembuktian; Tindak Pidana Informasi Elektronik

\section{A. Pendahuluan}

Perkembangan dan kemajuan di bidang teknologi informasi merupakan suatu hal yang tidak terelakkan di Era Revolusi Industri 4.0 ini. Perkembangan dan kemajuan di bidang teknologi informasi ini perlahan dan pasti mempengaruhi berbagai aspek di kehidupan masyarakat, salah satunya adalah hukum. Hal ini terjadi secara tidak langsung, di mana di dalam masyarakat (lapangan sosial) terjadi dinamika sosial dan perubahahan kultur yang bermuara pada permasalahan hukum, yang tentunya, menuntut sebuah penyelesaian hukum.

Kemudahan dalam menggunakan teknologi informasi dan komunikasi khususnya dengan menggunakan jaringan internet membawa pengaruh bagi perilaku masyarakat, termasuk 
bagaimana anggota masyarakat berinteraksi satu sama lainnya. Oleh karena itu, maka tidaklah heran jika permasalahan hukum yang dijumpai di dalam masyarakat saat ini banyak berkaitan dengan permasalahan penyampaian informasi, komunikasi, dan/atau transaksi secara elektronik yang dilaksanakan melalui sistem elektronik. Demi menjaga ketertiban umum dan demi menjamin kesejahteraan masyarakat, maka hukum haruslah memasuki tahap perubahan. Hukum siber (cyber law) merupakan tuntuan yang tidak terelakkan bagi perubahan ini. Hukum siber hadir sebagai penyelesaian hukum atas permasalahan-permasalahan hukum yang terjadi di masyarakat, khususnya yang berkaitan dengan informasi dan transaksi elektronik.

Meningkatnya permasalahan hukum berkenaan dengan informasi dan transaksi elektronik sangatlah terasa akhir-akhir ini. Hal ini terlihat dari besarnya peningkatan jumlah kasus Tindak Pidana Informasi dan Transaksi Elektronik (ITE) yang masuk ke Pengadilan Negeri pada Tahun 2018. Tercatat 651 kasus yang masuk ke Pengadilan Negeri selama tahun $2018^{1}$.

Bukanlah suatu fakta yang keliru jika kasus-kasus ITE bertambah banyak ketika masyarakat dunia memasuki era Post-Truth yang memuncak di tahun 2016. Era ini ditandai dengan ketidakjelasannya informasi yang beredar di masyarakat, melalui media sistem elektronik (cyber space) $)^{2}$, apakah itu merupakan suatu kebenaran (fakta) ataukah hanya suatu kebohongan (rekayasa). Pencarian kebenaran terhadap suatu informasi yang didapat, dirasa tidaklah penting lagi dikala informasi tersebut telah diafirmasi oleh banyak orang. Masyarakat yang terbuai dengan kemudahan memperoleh dan menyebarkan informasi menjadi tersesat di dalamnya. Kesesatan informasi ini berpotensi menyebabkan kerugian materiil dan imateriil bagi pihak tertentu yang terkena dampak olehnya. Hal ini dapat dirasakan oleh masyarakat Indonesia secara luas ketika masa Kampanye Pemilihan Presiden tahun 2019. Simpang siurnya informasi di media sosial bahkan di media massa dapat menggiring opini masyarakat dengan kesesatan informasi yang secara sengaja disebarkan, sehingga menimbulkan keresahan di masyarakat.

Permasalahan yang terjadi di masyarakat yang berkenaan dengan ITE barulah menjadi suatu tindak pidana apabila kasus ini memenuhi unsur-unsur tindak pidana yang disyaratkan dalam ketentuan perundang-undangan, dalam hal ini adalah UU ITE. UU ITE baru berlaku sejak tahun 2008 dan mengalami perubahan di tahun 2016. UU ITE hadir sebagai perwujudan dari tuntutan permasalahan hukum yang terjadi di masyarakat yang kemudian diharapkan dapat dijadikan sebagai alat penegakan hukum bagi kejahatan dan pelanggaran di bidang ITE. Oleh karena itu, maka sebelum tahun 2008 permasalahan hukum yang terjadi berkaitan dengan ITE belum memiliki landasan hukum untuk memenuhi asas legalitas, sesuatu yang dituntu oleh

\footnotetext{
1 Tim Pokja Laporan Tahunan Mahkamah Agung Republik Indonesia, 2018, Laporan Tahunan 2018 Mahkamah Agung Republik Indonesia : Era Baru Peradilan Modern Berbasis Teknologi Informasi, Jakarta, Mahkamah Agung, hlm 108.

2 Agus Raharjo, 2002, Cybercrime : Pemahaman dan Upaya Pencegahan Kejahatan Berteknologi, Bandung, Citra Aditya Bakti, hlm. 4.
} 
sistem peradilan pidana di negara kita. Kejahatan dan pelanggaran di bidang ITE sebelum tahun 2008 hanya mengandalkan peran aktif hakim dalam melakukan penafsiran hukum ${ }^{3}$. Namun sejak adanya UU ITE, cyber crime mendapat tempatnya sendiri dalam sistem peradilan pidana di Indonesia.

UU ITE tidak serta merta secara efektif mempermudah penindakan cyber crime di Indonesia, hal ini dikarenakan UU No. 8 Tahun 1981 tentang Kitab Undang-Undang Hukum Acara Pidana (selanjutnya dalam artikel ini disebut KUHAP) yang berlaku di Indonesia hingga saat ini masih belum mengalami perubahan. Belum adanya penyesuaian isi KUHAP dengan isi UU ITE tentu menimbulkan kendala dalam lapangan praktik hukum. Hal ini menyebabkan hukum formil (hukum prosedural) dalam menegakkan cyber crime berjalan kurang efektif, terutama dalam urusan pembuktian. Jika hakim tidak aktif dalam menggali kebenaran materiil selama persidangan, maka UU ITE ini akan menjadi kurang efektif sebagai landasan pencarian keadilan. Artinya jika hakim secara konvensional hanya berpedoman pada hukum formal yang ada yakni, KUHAP, maka keadilan substantif akan sulit untuk diwujudkan, yang muncul menjadi hasil akhirnya adalah keadilan prosedural semata.

Berdasarkan uraian di atas maka permasalahan yang ditemui adalah untuk mewujudkan keadilan substantive terhadap kasus Tindak Pidana Informasi Elektronik akan menjadi sulit jika hakim hanya bersandar pada ketentuan peraturan perundang-undangan yang ada. UU ITE tidak akan cukup jika tidak diimbangi dengan peran aktif hakim untuk mengatasi ketiadaan ketentuan hukum formil (hukum procedural) yang mengaturnya. Pertanyaan mengenai seberapa penting peran aktif hakim dalam membuat terobosan hukum pada kasus-kasus Tindak Pidana Informasi Elektronik akan dibahas lebih jauh dalam artikel ini yang berjudul "Urgensi Peran Aktif Hakim Pada Peradilan Tindak Pidana Informasi Elektronik".

\section{B. Pembahasan}

\section{Peran Aktif Hakim Pada Peradilan Pidana di Indonesia}

Indonesia menganut sistem pembuktian menurut undang-undang secara negative (negatief wettelijk bewijstheorie). Menurut M. Yahya Harahap sistem pembuktian ini menggabungkan antara sistem pembuktian menurut keyakinan hakim dengan sistem pembuktian menurut undang-undang secara positif ${ }^{4}$. Hal ini dapat kita temui pada Pasal 183

\footnotetext{
${ }^{3}$ Penafsiran hukum yang biasa dilakukan oleh hakim apabila hal yang diatur tidaklah jelas ataupun tidak diatur secara eksplisit/terang terutama dalam hal yang menyangkut benda tidak berwujud (Pasal 503 KUH Perdata) adalah dengan menggunakan penafsiran ekstensif yakni melakukan perluasan makna. Contoh dalam kasus pencurian listrik, dapat dikenakan Pasal 362 KUHP, dikarenakan kata benda pada pasal tersebut ditafsirkan secara ekstensif/diperluas maknanya sehingga benda juga dimaknai sebagai aliran listrik. Jika dalam hal ITE, benda dapat juga dimaknai sebagai informasi elektronik

${ }^{4}$ Yahya M. Harahap, 2000, Pembahasan Permasalahan dan Penerapan KUHAP : Pemeriksaan Sidang Pengadilan, Banding, Kasasi, dan Peninjauan Kembali, Jakarta, Sinar Grafika, hlm 278.
} 
KUHAP bahwa seorang hakim tidak boleh menjatuhkan pidana apabila belum memperoleh sekurang-kurangnya dua alat bukti yang sah sebagaimana yang telah disebutkan dan diatur di dalam Pasal 184 KUHAP. Oleh karena itu kita mengenal asas Unus Testis Nullus Testis yang kerap ditemui di negara-negara yang menganut sistem pembuktian menurut undang-undang secara negatif.

Berdasarkan sistem pembuktian yang telah diuraikan di atas, dalam hal pemidanaan seorang terdakwa, hakim haruslah mendasarkan pemidanaannya tersebut pada pembuktian yang berganda (dubbelen grondslag) yakni pada Undang-Undang dan Keyakinan Hakim. Hal ini sebagaimana yang dikemukan oleh David Simons ${ }^{5}$. Pertama, pembuktian harus dilakukan menurut menurut undang-undang (undang-undang telah menentukan dan menyebutkan alatalat bukti yang sah dalam peradilan pidana). Kedua, keyakinan hakim harus didasarkan dengan alat bukti yang sah ${ }^{6}$.

Pembuktian yang berganda membuat seorang Hakim pada Peradilan Pidana tidak dapat membebaskan diri dari kewajiban dengan mendasarkan putusannya pada KUHAP atau ketentuan perundang-undangan yang berlaku. Artinya, alat bukti yang dijadikan sebagai dasar pemidanaan hanyalah alat-alat bukti yang disebutkan dalam KUHAP. Maka menjadi sia-sialah sebuah keyakinan hakim jika secara normatif suatu alat bukti tidak diatur dalam undangundang. Tidak hanya sampai di situ, penafsiran ekstensif yang boleh dilakukan oleh hakim menjadi sesuatu hal yang tidak bisa berdiri sendiri secara mutlak jika tidak diikuti dengan pembuktian berganda. Hal ini terjadi dikarenakan masih kentalnya tradisi Civil Law System yang masih mendominasi sistem hukum di Indonesia.

Dalam pembuktian berganda salah satu komponen di dalamnya adalah keyakinan hakim. Mengapa demikian? Dikarenakan peran hakim dalam hukum acara pidana di Indonesia sangatlah besar, sehingga keyakinan hakim menjadi salah satu aspek dari dasar pemidanaan. Menurut Andi Hamzah, seorang hakim harus aktif bertanya dan memberi kesempatan bagi para pihak (Pihak Jaksa Penuntut Umum dan Pihak Terdakwa) demi menggali dan menemukan kebenaran materiil. Hal ini sangat berbeda dengan hakim di negara Amerika Serikat (menganut asas accusatoir) yang hanya berperan sebagai wasit (referee) ${ }^{7}$.

UU Kekuasaan Kehakiman yang ada di Indonesia memberikan kewenangan bagi hakim untuk menemukan hukum (rechtsvinding). Meskipun demikian, Wirjono Prodjodikoro menolak pendapat bahwa hakim menciptakan hukum. Hakim hanya dapat merumuskan hukum. Dalam penemuan hukum, hakim hanya dapat berlandaskan pada yurisprudensi (persuasive

\footnotetext{
${ }^{5}$ Simons, D. (1925). Beknopte Handleiding tot het Wetboek van Strafvordering. Haarlem: De Erven F. Bohn, hlm 152.

${ }^{6}$ Aristo M.A. Pangaribuan, Arsa Mufti, Ichsan Zikry, 2017, Pengantar Hukum Acara Pidana Di Indonesia, Jakarta, Raja Grafindo, hlm 277.

${ }^{7}$ Andi Hamzah, 2009, Hukum Acara Pidana Indonesia, Jakarta, Sinar Grafika, hIm 102-103
} 
precedent) dan doktrin. Di Indonesia hakim pada peradilan pidana hanya dapat menentukan ketentuan hukum pidana apa yang dilanggar oleh seorang terdakwa ${ }^{8}$.

Berdasarkan Pasal 184 KUHAP, alat bukti yang sah adalah keterangan saksi, keterangan ahli, surat, petunjuk dan keterangan terdakwa. Hal ini berbeda dengan alat bukti menurut Criminal Procedure Law Amerika Serikat yakni real evidence, documentary evidence, testimonial evidence, judicial evidence ${ }^{9}$.

Dengan kakunya peran hakim dalam perihal pembuktian dapat menimbulkan potensi official misconduct oleh aparat penegak hukum dalam proses pengumpulan barang bukti, yang berakibat menimbulkan kerugian (mencederai hak) bagi tersangka. Hal inilah menjadi perhatian bagi pembuat RKUHP, di mana dalam rancangan ini ditemui sebuah lembaga baru yakni Lembaga Hakim Pemeriksa Pendahuluan. Hakim pemeriksa pendahuluan memiliki kewenangan untuk menentukan suatu alat bukti yang diperoleh secara tidak sah tidak dapat dijadikan sebagai alat bukti ${ }^{10}$. Hal baru seperti ini dapat ditemui di negara Amerika Serikat, dengan istilah Exclusionary Rules yakni suatu alat bukti yang diperoleh secara tidak sah tidak dapat digunakan sebagai alat bukti yang mengakibatkan batalnya alat bukti tersebut untuk diajukan ke persidangan. Namun hingga detik ini, dengan belum diundangkannya RKUHP, maka Exclusionary Rules belum berlaku di Indonesia ${ }^{11}$.

Berdasarkan uraian kajian teoritis di atas, maka dapat diketahui bahwa hingga saat ini, peran aktif hakim pada Peradilan Pidana di Indonesia masih sangatlah minim dikarenakan KUHAP belum mengadopsi kewenangan rechtsvinding yang ada di dalam UU Kekuasaaan Kehakiman. Dengan masih berlakunya KUHAP, maka kedudukan hakim hanya sebatas corong undang-undang (la bouche de la lol) sebagaimana yang dikemukakan oleh Montesquieu.

"Mais les juges de la nation ne sont, comme nous avons dit, que la bouche qui pronounce les paroles de la loi, des ètres inanimés qui n'en peuvent modérer ni la force ni la rigueur."

Montesquieu menyatakan bahwa para hakim hanya dapat menyuarakan Undang-undang, atau hanya sebagai mulut dari Undang-Undang. Hakim tidak dapat mengubah kekuatan dan kekakuan dari hukum itu, artinya hakim tidak dapat mengubah, menambahkan, mengurangi bahkan membuat peraturan baru, selain daripada undang-undang yang berlaku. Hal ini dikarenakan pembuatan hukum hanya berada di tangan kekuasaan Badan Legislatif ${ }^{13}$.

\footnotetext{
${ }^{8}$ Wirjono Prodjodikoro, 1967, Bunga Rampai hukum, Jakarta, Ichtiar Baru, hlm 29

${ }^{9}$ Andi Hamzah, Op.cit, hlm 287.

${ }^{10}$ Pangaribuan, et.al, Op.cit, hlm 290

${ }_{11}^{11}$ Romly Atmasasmita, 1983, Bunga Rampai Hukum Acara Pidana, Bandung, Binacipta, hlm 54

${ }_{12}$ M. Montesquieu, 1872, Esprit Des Lois, Paris, Librairie de Firmin Didot Freres, Fils et Cie, hlm 134

${ }^{13} \mathrm{lbid}, \mathrm{hlm} 135$
} 


\section{Urgensi Peran Aktif Hakim Pada Peradilan Tindak Pidana Informasi Elektronik}

Tindak Pidana Informasi Elektronik merupakan tindak pidana dalam bentuk kegiatan yang dilakukan melalui media sistem elekronik atau yang disebut sebagai Ruang Siber (Cyber Space). Kegiatan di cyber space ini bersifat virtual namun mempunyai dampak nyata, yakni memiliki akibat hukum. Namun secara normatif, sebelum berlakunya UU ITE, terhadap kegiatan di cyber space ini tidak dapat dikenakan pendekatan yuridis berdasarkan ketentuan hukum konvensional. Hal ini dikarenakan tidak adanya peraturan perundang-undangan yang mengatur secara terang, untuk dapat dijadikan sebagai suatu landasan hukum bagi kegiatan di cyber space ini bisa disebut sebagai suatu peristiwa hukum. Dewasa ini, kasus Tindak Pidana Informasi Elektronik yang paling sering didengan oleh masyarakat adalah mengenai kasus penyebaran hoax, hal ini mulai santer terdengar ketika memasuki tahun 2018.

Meskipun diakukan secara virtual, dengan berlakunya UU ITE, maka perbuatan yang dilakukan oleh subjek hukum di cyber space merupakan perbuatan hukum yang menimbulkan akibat hukum yang dikehendaki. Untuk membuktikan adanya peristiwa hukum di cyber space maka diperlukan suatu alat bukti, yakni alat bukti elektronik. Menurut UU ITE, meskipun tidak secara terang disebutkan, alat bukti elektronik dapat berbentuk Informasi Elektronik, Dokumen Elektronik dan Tanda Tangan Elektronik (Pasal 5 UU ITE). Namun dalam ketentuan ini ada pengecualian. Alat bukti elektronik tidak dapat menjadi alat bukti yang sah apabila terkait dengan pembuatan, yakni surat yang menurut undang-undang harus dibuat dalam bentuk tertulis dan Surat beserta dokumennya yang menurut undang-undang harus dibuat dalam bentuk akta notariil (Pasal 5 ayat (4) UU ITE) ${ }^{14}$.

Menurut David Chaikin, Alat Bukti elektronik (digital evidence) adalah representasi informasi yang disimpan dalam computer, melewati/melalui sebuah computer, atau diekstrasi dari sebuah computer yang menggunakan angka (misalnya binary digits/bits) yang tidak dapat diakses dengan panca indera manusia dan hanya bisa diterjemahkan dengan bantuan seorang pakar IT. Media yang menyimpan alat bukti elektronik ini tidak hanya terbatas pada media komputer saja, namun juga melalui media perangkat elektronik lainnya seperti audio, video, alat komunikasi, dan perangkat fotografi ${ }^{15}$.

Alat bukti elektronik memiliki beberapa karakteristik. Pertama, alat bukti elekronik dapat mudah disalin dan dimodifikasi, namun tidak mudah untuk disimpan dalam keadaan asli. Kedua, sumber asli dari sebuah alat bukti elektronik sulit untuk dibuktikan. Ketiga, presentasi informasi digital tidak dapat dideteksi (dilihat, diraba dan dirasa) oleh panca indera manusia ${ }^{16}$.

\footnotetext{
14 Johan Wahyudi, 2012, "Dokumen Elektronik Sebagai Alat Bukti Pada Pembuktian di Pengadilan". Jurnal Perspektif, Vol 17, Issue 2, Mei 2012, hIm 123

${ }^{15}$ David Chaikin, 2006, "Network Investigations of Cyber Attacks : The Limits of Digital Evidence", Crime, Law and Social Change, Vol 46 , Issue 4-5, hlm 240-241

${ }_{16}$ Shiuh-Jeng Wang, 2007, "Measures of Retaining Digital Evidence to Prosecute Computer-Based Cyber-Crimes". Computer Standards \& Interfaces, Vol 29, Issue 2, hlm 217
} 
Menurut Isma dan Koyimatun, ada 9 (sembilan) peraturan perundang-undangan yang mengatur tentang alat bukti elekronik, diantaranya UU Dokumen Perusahaan, UU TIPIKOR, UU Terorisme, UU Tindak Pidana Perdagangan Orang, UU Narkotika, UU Tindak Pidana Pencucian Uang, UU Tindak Pidana Pendanaan Terorisme, UU Pencegahan dan Pemberantasan Perusakan Hutan, UU Hak Cipta ${ }^{17}$. Lebih lanjut lagi, dari kesembilan peraturan perundang-undangan di atas, memiliki dua pandangan yang berbeda terhadap alat bukti elektronik. Pandangan pertama menganggap bahwa pengkategorian bukti yang sudah ada tidaklah berdiri sendiri. Hal ini bisa kita lihat pada UU Dokumen Perusahaan dan UU TIPIKOR. UU Dokumen Perusahaan memberi perluasan dari makna alat bukti surat (Pasal 184 KUHAP), sehingga alat bukti elektronik masuk dalam peluasan makna alat bukti surat. Sedangkan pandangan kedua menganggap bukti elektronik merupakan alat bukti yang berdiri sendiri. Artinya, pengaturan tentang alat bukti elektronik terpisah dari Pasal 184 KUHAP dan berdiri sendiri. Pengaturan mengenai hal ini dapat ditemui pada UU Terorisme, UU Tindak Pidana Perdagangan Orang, UU Narkotika, UU Tindak Pidana Pencucian Uang, UU Pencegahan dan Pemberantasan Kerusakan Hutan, dan UU Hak Cipta ${ }^{18}$.

Alat bukti elektronik telah direncanakan untuk diatur di dalam Rancangan KUHAP (selanjutnya dalam artikel ini disebut sebagai RKUHAP). Pengertian mengenai alat bukti elektronik dijabarkan di dalam penjelasan Pasal 177 ayat (1) huruf c RKUHAP.

"Alat bukti elektronik adalah informasi yang diucapkan, dikirim, diterima, atau disimpan secara elekronik dengan alat optik atau yang serupa dengan itu, termasuk setiap rekaman data atau informasi yang dapat dilihat, dibaca dan/atau didengar yang dapat dikeluarkan dengan atau tanpa bantuan suatu sarana baik yang tertuang di atas kertas, benda fisik apapun selain kertas maupun yang terekam secara elektronik yang berupa tulisan, gambar, peta, rancangan, foto, huruf, tanda, angka atau perforasi yang memiliki makna."19

Alat Bukti elektronik telah direncanakan untuk diatur pada Pasal 175 RKUHP. Pasal tersebut menyebutkan bahwa alat bukti yang sah menurut undang-undang tersebut adalah berupa barang bukti, surat-surat, bukti elektronik, keterangan seorang ahli, keterangan seorang saksi, keterangan terdakwa dan pengamatan hakim ${ }^{20}$.

\footnotetext{
${ }^{17}$ Nur Laili Isma, Arima Koyimatun, 2014, "Kekuatan Pembuktian Alat Bukti Informasi Elektronik Pada Dokumen Elektronik Serta Hasil Cetaknya Dalam Pembuktian Tindak Pidana”, Jurnal Penelitian Hukum, Vol 1, Issue 2, hlm 111

18 Ibid, hlm 111-112

19 Syaibatul Hamdi, Suhaimi, dan Mujibussalim, 2013, "Bukti Elektronik Dalam Sistem Pembuktian Pidana", Jurnal Ilmu Hukum Universitas Syiah Kuala, Vol 1, Issue 3, hIm 28

20 Muslim Mamulai, 2017, "Hakikat Pembuktian Melalui Media Elektronik Dalam Perspektif Sistem Peradilan Pidana Indonesia". Jurnal Al-Ishlah, Vol 19, Issue 1, hlm 33
} 
Dalam praktik peradilan pidana saat ini, telah ada beberapa putusan pengadilan yang telah menggunakan alat bukti elektronik dalam proses pembuktiannya. Di antaranya, Putusan Pengadilan Negeri Jakarta Pusat No. 1361Pid.B/2005/PN.Jak.Pst, dalam perkara pidana ini Jaksa Penuntut Umum (JPU) mengajukan alat bukti elektronik berupa hasil cetak dari call data resource (CDR) yang diperoleh (dikeluarkan) dari salah satu perusahaan provider telekomunikasi ${ }^{21}$.

Selain itu berdasarkan penelusuran oleh Penulis, ada beberapa putusan lainnya yang telah menggunakan alat bukti elektronik sebagai alat bukti di muka peradilan. Pada Putusan Pengadilan Negeri Kendal No. 72/Pid.Sus/2018/PN.Kdl, dimana Jaksa Penuntut Umum mengajukan bukti handphone dan data-data di dalamnya yang merupakan milik terdakwa, kemudian juga dijadikan sebagai alat bukti yakni sebuah tautan akun facebook milik terdakwa dan screen capture laman facebook yang dijadikan sebagai bukti bahwa terdakwa telah melakukan penyebaran hoax yang memenuhi pasal 45 A ayat (2) UU ITE. Alat bukti yang serupa juga ada dalam Pembuktian yang tertulis dalam Putusan Pengadilan Negeri Jakarta Utara No. 1105/Pid.Sus/2017/PN.Jkt.Utr dan Putusan Pengadilan Negri Sleman No. 197/Pid.Sus/2018/PN.Smn, namun untuk media yang digunakan selain handphone juga sebagai alat bukti adalah laptop dan data-data di dalamnya.

Seperti yang telah dikemukakan oleh penulis di sub-bab sebelumnya, bahwasanya peran aktif hakim pada Peradilan Pidana di Indonesia masih sangatlah terbatas dikarenakan KUHAP belum mengadopsi kewenangan rechtsvinding yang ada di dalam UU Kekuasaaan Kehakiman. Namun meskipun demikian, bahwa bukanlah salah jika Hakim dapat menggunakan kewenangannya yang diberikan oleh UU Kekuasaan Kehakiman untuk melakukan rechtstvinding. Memang tidaklah disebutkan secara terang pada Pasal 5 ayat (1) UU Kekuasaan Kehakiman, yang termaktub adalah Hakim dan Hakim Konstitusi wajib menggali, mengikuti dan memahami nilai-nilai hukum dan rasa keadilan yang hidup dalam masyarakat. Namun oleh beberapa literatur disebutkan bahwa Pasal ini merupakan pasal Rechtsvinding ${ }^{22}$.

Beberapa putusan yang memasukan alat bukti elektronik sebagai pembuktian di muka persidangan, adalah salah satu bukti bahwa para hakim di Indonesia telah memanfaatkan kewenangannya untuk melakukan seuatu penerobosan hukum yakni berupa penemuan hukum, dikarenakan terjadinya kekosongan hukum dimana KUHAP belum mengatur mengenai alat bukti elektronik. Sehingga di sini, hakim bertindak sebagai quasi-legislative discretion ${ }^{23}$. Quasilegislative discretion memang umum ditemui pada negara-negara yang didominasi oleh tradisi

\footnotetext{
21 Josua Sitompul, 2001, Hukum Internet (Pengenalan Mengenai Masalah Hukum di Cyberspace), Bandung, Citra Aditya Bakti, hlm 298

22 Siti Malikhatun Badriyah, 2011, "Penemuan Hukum (Rechtsvinding) dan Penciptaan Hukum (Rechtsschepping) Hakim Untuk Mewujudkan Keadilan", Masalah-Masalah Hukum, Vol 40, Issue 3, Juli 2011, hlm 391

${ }^{23}$ E. Philip Soper, 1977, "Legal Theory and The Obligation of a Judge: The Hart/Dworkin Dispute", Michigan Law Review, Vol 75, Issue 3, hlm 513
} 
hukum Common Law System. Oleh karena itu, KUHAP yang merupakan warisan Hukum Kolonial Hindia Belanda yang sangat dipengaruhi oleh tradisi hukum Civil Law System, sama sekali tidak memberikan ruang bagi hakim untuk melakukan penemuan hukum.

Dari beberapa putusan yang telah dikemukakan di atas, telah membuktikan bahwa Hakim selain telah menggunakan kewenangannya untuk melakukan rechtsvinding dan tidak sekedar melakukan penerapan hukum (rechttoepassing) ${ }^{24}$ berdasarkan undang-undang yang berlaku, hakim juga telah memposisikan diri sebagai quasi-legislative yang membuat sebuah diskresi hukum dimana terjadi kekosongan hukum. Berdasarkan UU Kekuasaan Kehakiman, maka para hakim yang telah memutus dengan alat bukti elektronik tidaklah salah. Hal ini dikarenakan hakim Peradilan Pidana memang dituntut untuk secara aktif menemukan kebenaran materiil dari suatu perkara pidana yang diadilinya. Tentu mencari suatu kebenaran materiil tidaklah mudah. Hakim dituntut untuk secara aktif melakukan hal-hal yang dipandang perlu bahkan harus melakukan penerobosan hukum demi menggali kebenaran materiil yang terkadang terbatas untuk didapatkan dari pembuktian yang ada. UU Kekuasaan Kehakiman merupakan dasar legitimasi dari seorang Hakim pada Peradilan Pidana untuk dapat secara aktif melakukan penemuan hukum termasuk di dalamnya memperluas penafsiran makna alat bukti yang diatur di dalam Pasal 184 KUHAP.

Berdasarkan uraian di atas, menurut penulis ada beberapa urgensi peran aktif hakim yang harus dilakukan berkaitan dengan kasus Tindak Pidana Informasi Elektronik.

Pertama, suatu putusan seharusnya mampu mengakomodir tiga nilai hukum yakni kepastian hukum, kemanfaatan dan keadilan ${ }^{25}$. Jika hakim hanya mengandalkan KUHAP yang berlaku saat ini, maka sulit untuk menjamin kemanfaatan dan keadilan dapat terwujudkan dalam sebuah putusan hakim. Dalam Tindak Pidana Informasi Elektronik, hakim tidak hanya sekedar menerapkan suatu hukum positif ke dalam sebuah fakta hukum. Hal ini dikarenakan peraturan yang mengatur tentang Tindak Pidana Informasi Elektronik hanyalah berupa hukum materiil yakni UU ITE. Sedangkan hukum formil yang mengatur tentang Tindak Pidana Informasi Elektronik belum ada (tidak diatur dalam KUHAP). Hakim haruslah berperan aktif dengan tidak hanya sekedar melakukan penerapan hukum (rechttoepassing) melainkan juga melakukan penemuan hukum. Metode Penemuan hukum dapat berupa Penafsiran Hukum, Analogi (Argumentum Per Analogiam), Argumentum a Contrario ${ }^{26}$, Penyempitan Hukum

\footnotetext{
${ }^{24}$ Siti Malikhatun Badriyah, Op.Cit, hlm 388

${ }^{25}$ Gustav Radbruch, 2006, "Statutory Lawlessness and Supra-Statutory Law", Oxford Journal of Legal Studies, Vol 26, Issue 1, hlm 6

${ }^{26}$ Argumentum a Contrario adalah sebuah penemuan hukum oleh hakim, apabila didapati suatu peristiwa yang diadili tidak sama dengan peristiwa hukum yang diatur oleh ketentuan hukum yang berlaku, maka terhadap peristiwa tersebut diberlakukan ketentuan yang sebaliknya dari ketentuan hukum yang ada tersebut
} 
(Rechtsverfijning), Eksposisi ${ }^{27}$. Berdasarkan putusan-putusan hakim yang telah memutus perihal Tindak Pidana Informasi Elektronik, hakim yang memutus tersebut melakukan penafsiran hukum dengan metode Ekstensif, dimana hakim melakukan perluasan makna dari alat bukti surat yang ditulis dalam Pasal 184 KUHAP.

Kedua, saat ini jumlah kasus Tindak Pidana Informasi Elektronik yang masuk ke Pengadilan Negeri semakin meningkat, seiring munculnya sentimen positif oleh masyarakat. Bermunculannya hakim-hakim yang sudah mulai 'berani' melakukan penemuan hukum dan memunculkan putusan-putusan yang menimbulkan reaksi positif dari masyarakat. Hakim tidak hanya sekedar mengejar kepastian hukum namun juga berusaha untuk mengakomodir kemanfaatan dan keadilan dalam putusannya. Hal ini menimbulkan rasa percaya bagi masyarakat terhadap pengadilan sebagai suatu institusi hukum. Namun alasan mengapa jumlah kasus Tindak Pidana Informasi Elektronik yang masuk ke Pengadilan ini semakin meningkat, bukan hanya karena sentiment positif masyarakat namun adanya tren baru di masyarakat, di mana masyarakat memandang bahwa penyelesaian suatu permasalahan hukum hanyalah melalui proses litigasi. Hal inilah yang membuat peningkatan jumlah aduan kasus Tindak Pidana Informasi Elektroik yang masuk ke unit cyber crime yang bermuara hingga Proses Peradilan. Dengan banyaknya jumlah kasus ini, maka Hakim haruslah aktif dalam mencari kebenaran materiil dalam mengadili kasus Tindak Pidana Informasi Elektronik. Hakim tidak boleh 'malas' dalam melakukan penemuan hukum meskipun dengan adanya keterbatasan hukum yang berlaku. Hakim harus aktif menghadirkan alat bukti elektronik di persidangan meskipun (jika dalam hal) tidak masuk dalam alat bukti yang diminta oleh para pihak (Jaksa Penuntut Umum dan Terdakwa).

Dari kedua hal yang telah dikemukakan oleh Penulis di atas, maka peran aktif hakim dalam Tindak Pidana Informasi Elektronik paling dibutuhkan pada tahap Pembuktian. Peran aktif hakim dapat berupa : Pertama, meminta dihadirkannya alat bukti elekronik yang dipandang perlu meskipun tidak tercantum dalam KUHAP. Kedua, hakim dapat menggunakan kewenangannya melakukan penemuan hukum (rechtsvinding) dengan melakukan penafsiran ekstensif, memperluas makna alat bukti surat pada Pasal 184 KUHAP.

Peran aktif hakim ini sekaligus mendobrak kekakuan yang dimiliki oleh KUHAP sekaligus menghadirkan keadilan substantif yang dicita-citakan oleh masyarakat luas.

\section{Simpulan}

Berdasarkan pembahasan yang telah diuraikan oleh Penulis di atas,maka ada beberapa hal yang dapat disimpulkan dari uraian tersebut.

${ }^{27}$ Sudikno Mertokusumo, 2007, Penemuan Hukum : Sebuah Pengantar, Yogyakarta, Liberty, hlm 56-73 
Pertama, Peran aktif Hakim pada Peradilan Pidana di Indonesia masih minim dan terbatas pergerakannya oleh karena adanya KUHAP yang masih berlaku hingga detik ini. Hal ini dikarenakan KUHAP belum mengadopsi rechtsvinding yang sebenarnya telah termaktub dalam UU Kekuasaan Kehakiman. Banyak hakim yang belum berani dan hanya sekedar menerapkan hukum positif yang ada, meskipun telah diketahui tidak salah seorang hakim melakukan penemuan hukum di Indonesia. KUHAP merupakan produk dominasi tradisi Civil Law System yang membatasi hakim hanya sebagai corong/mulut Undang-Undang.

Kedua, Penulis menemukan dua Urgensi Peran hakim pada Peradilan Tindak Pidana Informasi Elektronik. Yang pertama, dalam putusan hakim haruslah mengakomodir kepastian hukum, kemanfaatan dan keadilan. Sehingga hal ini menimbulkan urgensi hakim untuk aktif melakukan penemuan hukum. Yang kedua, meningkatnya jumlah kasus Tindak Pidana Informasi Elektronik menuntut kerja keras hakim untuk menjaga sentiment positif dari masyarakat. Hakim tidak boleh 'malas' dalam menghadirkan alat bukti elektronik sebagai pembuktian di kasus Tindak Pidana Informasi Elektronik, meskipun tidak diatur di dalam KUHAP.

\section{DAFTAR PUSTAKA}

\section{Buku}

Atmasasmita, R. (1983). Bunga Rampai Hukum Acara Pidana. Bandung: Binacipta.

Hamzah, A. (2009). Hukum Acara Pidana. Jakarta: Sinar Grafika.

Harahap, Y. (2003). Pembahasan, Permasalahan dan Penerapan KUHAP (Penyidikan dan Penuntutan). Jakarta: Sinar Grafika.

Mertokusumo, S. (2007). Penemuan Hukum: Sebuah Pengantar. Yogyakarta : Liberty.

Montesquieu, M. (1872). Esprit Des Lois. Paris: Librairie de Firmin Didot Freres, Fils et Cie.

Pangaribuan, A. M. A., Mufti, A., \& Zikry, I. (2017). Pengantar Hukum Acara Pidana di Indonesia. Jakarta: PT. Raja Grafindo Persada.

Raharjo, A. (2002). Cybercrime: Pemahaman dan upaya pencegahan kejahatan berteknologi. Bandung: Citra Aditya Bakti.

Simons, D. (1925). Beknopte Handleiding tot het Wetboek van Strafvordering. Haarlem: De Erven F. Bohn.

Sitompul, J. (2001). Hukum Internet (Pengenalan Mengenai Masalah Hukum di Cyberspace), Bandung : Citra Aditya Bakti

Prodjodikoro, W. (1967). Bunga Rampai hukum. Jakarta: Ichtiar Baru. 


\section{Jurnal}

Badriyah, S. M. (2011). Penemuan Hukum (Rechtsvinding) dan Penciptaan Hukum (Rechtsschepping) Hakim Untuk Mewujudkan Keadilan. Masalah-Masalah Hukum, 40(3), 384-392. https://doi.org/10.14710/mmh.40.3.2011.384-392

Chaikin, D. (2006). Network Investigations of Cyber Attacks: The Limits of Digital Evidence. Crime, Law and Social Change, 46(4-5), 239-256. https://doi.org/10.1007/s10611-0079058-4

Hamdi, S., Suhaimi, S., \& Mujibussalim, M. (2013). Bukti Elektronik Dalam Sistem Pembuktian Pidana. Jurnal IImu Hukum Universitas Syiah Kuala, 1(3), 25-31.

Isma, N. L., \& Koyimatun, A. (2014). Kekuatan Pembuktian Alat Bukti Informasi Elektronik Pada Dokumen Elektronik Serta Hasil Cetaknya Dalam Pembuktian Tindak Pidana. Jurnal Penelitian Hukum, 1(2), 109-116.

Mamulai, M. (2017). Hakikat Pembuktian Melalui Media Elektronik Dalam Perspektif Sistem Peradilan Pidana Indonesia. Jurnal Al-Ishlah, 19(1), 31-48. Retrieved from http://jurnal.fh.umi.ac.id/index.php/ishlah/article/view/22/6

Radbruch, G. (2006). Statutory Lawlessness and Supra-Statutory Law. Oxford Journal of Legal Studies, 26(1), 1-11. https://doi.org/10.1093/ojls/gqi041

Soper, E. P. (1977). Legal Theory and The Obligation of a Judge: The Hart/Dworkin Dispute. Michigan Law Review, 75(3), 473-519. https://doi.org/10.2307/1287980

Wahyudi, J. (2012). Dokumen Elektronik Sebagai Alat Bukti Pada Pembuktian di Pengadilan. Perspektif, 17(2), 118-126. http://dx.doi.org/10.30742/perspektif.v17i2.101

Wang, S.-J. (2007). Measures of Retaining Digital Evidence to Prosecute Computer-Based Cyber-Crimes. Computer Standards \& Interfaces, 29(2), 216-223. https://doi.org/10.1016/j.esi.2006.03.008

\section{Laporan}

Mahkamah Agung. (2018). Laporan Tahunan 2018 Mahkamah Agung: Era Baru Peradilan Modern Berbasis Teknologi Informasi. Jakarta. 